\title{
PENGARUH PENGGUNAAN MEDIA AUDIO VISUAL PEMBELAJARAN TERHADAP KETERAMPILAN PROSES IPA DAN HASIL BELAJAR IPA PADA SISWA KELAS V SD NEGERI 1 BONEATIRO
}

\author{
Ardy Lestary Awaluddin Rasyid \\ Prodi Pendidikan Guru Sekolah Dasar, Fakultas Keguruan dan Ilmu Pendidikan \\ Universitas Muhammadiyah Buton, Jl. Betoambari No. 36 Baubau. \\ E-mail: ardylestaryawaluddinrasyid@gmail.com
}

\begin{abstract}
Abstrak
Penelitian ini bertujuan untuk mengetahui Pengaruh penggunaan media audio visual pembelajaran dan Pengaruh penggunaan media audio visual terhadap hasil belajar IPA pada siswa kelas V SD Negeri 1 Boneatiro Kabupaten Buton Tahun Pelajaran 2018/2019. Populasi penelitian ini adalah seluruh Kelas V SD Negeri 1 Boneatiro, dengan sampel kelas VB sebagai kelas eksperimen dan VA sebagai kelas kontrol. Hasil penelitian menunjukan bahwa, hasil post-test keterampilan proses IPA kelas eksperimen yaitu 62,14, kelas kontrol yaitu 53,86 dan nilai $t_{\text {hitung }} 4,155>t_{\text {tabel. }}$. Post-test hasil belajar IPA kelas eksperimen yaitu 80,00, kelas kontrol yaitu 70,86 dan nilai $t_{\text {hitung }} 3,915>t_{\text {tabel }}$. Artinya ada perbedaan yang signifikasn antara hasil posttest kelas eksperimen yang menggunakan media audio visual pembelajaran dengan kelas kontrol yang menggunakan media gambar. Hasil analisis korelasi diperoleh 0,945 kelas eksperimen dan 0,944 kelas kontrol. Artinya ada hubungan positif sangat kuat antara keterampilan proses dan hasil belajar IPA. Sehingga disimpulkan terdapat pengaruh penggunaan media audio visual pembelajaran terhadap keterampilan proses dan hasil belajar IPA, dan terdapat hubungan positif sangat kuat antara keterampilan proses dan hasil belajar IPA pada siswa Kelas V SD Negeri 1 Boneatiro 1.
\end{abstract}

Kata Kunci: Media Audio Visual, Pembelajaran, Keterampilan Proses.

\footnotetext{
Abstract

This study aims to determine the effect of the use of audio visual media learning and the effect of the use of audio visual media on science learning outcomes in fifth grade students of SD Negeri 1 Boneatiro, Buton Regency, Academic Year 2018/2019. The population of this study was all Class V SD Negeri 1 Boneatiro, with samples of VB class as experimental class and VA as control class. The results showed that the results of the post-test skills of the experimental class science process were 62.14, the control class was 53.86 and the tcount was 4.155> $t$ table. The experimental class experimental post-test results of 80.00 , control class 70,86 and tcount 3,915> $t$ table. This means that there is a significant difference between the results of the experimental class post-test using audio-visual learning media and the control class using image media. The results of the correlation analysis obtained 0.945 experimental class and 0.944 control class. This means that there is a very strong positive relationship between science process skills and learning outcomes. So it can be concluded that there is the effect of using audio visual media learning on science process and learning outcomes skills, and there is a very strong positive relationship between science process skills and learning outcomes in Class V students of SD 1 Boneatiro 1.
} 


\section{SANG PENCERAH}

Volume 4, Nomor 2, Agustus 2018, Hlm. 1-11

Ardy Lestary A.R.: Pengaruh Penggunaan Media Audio Visual ...

Keywords: Audio Visual Media, Learning, Process Skills. 


\section{SANG PENCERAH}

Volume 4, Nomor 2, Agustus 2018, Hlm. 1-11

Ardy Lestary A.R.: Pengaruh Penggunaan Media Audio Visual ...

\section{Pendahuluan}

Berdasarkan UU Republik Indonesia No. 20 Tahun 2003 tersebut, salah satu tujuan pendidikan adalah untuk mengembangkan potensi dan keterampilan siswa sehingga potensi dan keterampilan siswa juga semakin berkembang. Dengan berkembangnya potensi dan keterampilan siswa, maka berbagai bidang dalam kehidupan juga ikut berkembang. Dunia informasi adalah salah satu bidang yang berkembang pesat dan paling berpengaruh di berbagai aspek kehidupan masyarakat, termasuk aspek pendidikan. Saat ini banyak teknologi modern yang sering digunakan oleh masyarakat. Baik itu televisi, radio, tape recorder, VCD, bahkan LCD dan komputer. Pada awalnya teknologi seperti VCD, LCD, komputer adalah barang mewah yang jarang dimiliki masyarakat, tetapi saat ini telah menjadi barang yang umum digunakan. Tidak hanya digunakan untuk konsumsi pribadi, hiburan atau digunakan kantor perusahaan, kini produk teknologi modern juga telah merambah di dunia pendidikan. Kehadiran teknologi yang modern sekolah dituntut untuk lebih kreatif dalam membuat pembelajaran menjadi menarik dan efektif, baik dalam proses pembelajaran maupun media pembelajaran sehingga siswa akan menjadi senang dan tidak bosan selama proses pembelajaran berlangsung dan memperoleh hasil belajar maksimal.

Salah satu mata pelajaran yang diajarkan dalam pembelajaran di Sekolah Dasar (SD) adalah Ilmu Pengetahuan Alam (IPA). Pada dasarnya IPA memiliki tiga komponen utama seperti yang diungkapkan Patta Bundu (dalam Binti Muakhirin, 2014: 51), yaitu komponen proses ilmiah, produk ilmiah, dan sikap ilmiah. Dengan demikian IPA bukanlah mata pelajaran yang berisikan kumpulan materi saja. Oleh karena itu, pembelajaran IPA perlu didesain sebaik mungkin tidak hanya bertujuan menyampaikan materi, namun juga dapat menumbuhkan kemampuan berpikir, bekerja, dan dapat mengembangkan keterampilan proses siswa.

Pada proses pembelajaran saat ini terutama pada materi tentang IPA, pembelajaran juga menekankan pada keterampilan proses pada siswa. Menurut Depdiknas, (dalam Zulvia, 2013: 6) Ilmu Pengetahuan Alam (IPA) berkaitan dengan cara mencari tahu mengenai alam. Sedangkan keterampilan proses IPA merupakan keterampilan intelektual yang dimiliki para ilmuan dan digunakan oleh para ilmuan dalam meneliti fenomena alam. Dilihat dari pengertian tersebut, keterampilan proses IPA dimaksudkan untuk memberikan pemahaman kepada siswa dalam mengenal dan memahami materi menggunakan pendekatan ilmiah.

Berdasarkan hasil observasi, perlu diadakan perbaikan dalam keterampilan proses IPA dan hasil belajar IPA. Hal tersebut perlu mendapat perhatian yang lebih agar siswa mengerti akan keterampilan proses IPA dan hasil belajar IPA siswa bisa meningkat. Salah satu caranya yaitu menggunakan media audia visual pada proses pembelajaran Dengan penggunaan media audio visual pada pembelajaran IPA, siswa akan lebih bersemangat dalam belajar karena media audio visual menarik perhatian siswa dan memudahkan dalam menyampaikan materi kepada siswa. Salah satu materi yang diajarkan pada materi IPA kelas $\mathrm{V}$ adalah mengenai sistem pencernaan dan pernafasan manusia dan hewan. Pada materi pencernaan dan pernafasan guru kesulitan menghadirkan media benda asli. Materi ini sulit apabila disampaikan menggunakan benda aslinya. Salah satu alternatif agar pembelajaran dapat berlangsung secara efisien adalah menggunakan media audio visual pembelajaran. Peneliti memilih media audio visual pembelajaran karena media audio visual pembelajaran dapat menampilkan informasi yang tadinya tidak bisa dilihat secara langsung oleh indra penglihatan 


\section{SANG PENCERAH}

Volume 4, Nomor 2, Agustus 2018, Hlm. 1-11

Ardy Lestary A.R.: Pengaruh Penggunaan Media Audio Visual ...

siswa menjadi bisa terlihat oleh indra penglihatan siswa. Siswa dapat melihat organ dalam pada tubuh manusia dan hewan tanpa harus membedah objek aslinya, dengan audio visual, siswa juga akan melihat langsung proses pencernaan dan pernafasan pada manusia dan hewan melalui sebuah animasi. Media audio visual pembelajaran dapat mewujudkan visualisasi materi sistem pencernaan dan pernafasan tersebut.

Tujuan penelitian ini adalah untuk mengetahui Pengaruh penggunaan media audio visual pembelajaran dan Pengaruh penggunaan media audio visual terhadap hasil belajar IPA pada siswa kelas V SD Negeri 1 Boneatiro Kabupaten Buton Tahun Pelajaran 2018/2019.

\section{Metode Penelitian}

Metode dalam penelitian ini adalah metode Quasi Eksperimental Design (penelitian eksperimen semu). Quasi Eksperimental Design bertujuan untuk mengetahui perbedaan antara dua variabel atau lebih kelompok yang menjadi subjek penelitian. (Sugiyono, 2012: 114).

Sampel penelitian akan dibagi kedalam dua kelompok, yaitu kelompok kelas eksperimen dan kelompok kelas kontrol. Kelompok kelas eksperimen akan diberi perlakuan menggunakan media audio visual pembelajaran dengan materi pokok Organ Tubuh Manusia dan Hewan. Kelompok kelas kontrol tidak diberi perlakuan menggunakan media audio visual pembelajaran, tetapi pembelajaran yang biasa dilakukan oleh guru yaitu menggunakan buku siswa dan gambar sederhana dengan materi pokok Organ Tubuh Manusia dan Hewan.

Penelitian ini dilaksanakan pada semester ganjil tahun ajaran 2018/2019 bulan juli 2018 di kelas V SD Negeri 1 Boneatiro Kabupaten Buton Tahun Pelajaran 2018/2019 sebagai tempat penelitian karena sekolah ini memenuhi kriteria untuk dilakukan penelitian yaitu terdapat kelas paralel yang dapat mendukung pelaksanaan penelitian.

Populasi dari penelitian ini adalah seluruh kelas V di SD Negeri 1 Boneatiro Kabupaten Buton pada semester Ganjil Tahun Pelajaran 2018/2019 yang berjumlah 56 siswa, terdiri dari kelas VA 28 Siswa dan kelas VB 28 Siswa sedangkan sampel dalam penelitian adalah bagian dari jumlah dan karakteristik yang dimiliki oleh populasi tersebut. Pengambilan sampel penelitian ini dengan teknik random. Yang menjadi sampel dalam penelitian ini adalah kelas VA sebagai kelas eksperimen dan VB sebagai kelas kontrol di SD Negeri 1 Boneatiro Kabupaten Buton Tahun Pelajaran 2018/2019.

Data yang ingin diperoleh dalam penelitian ini adalah data keterampilan proses IPA dan hasil belajar IPA siswa, untuk itu dalam penelitian ini akan menggunakan teknik tes dan observasi. Teknik tes dalam penelitian ini adalah tes keterampilan proses IPA dan hasil belajar IPA yang digunakan selama dua kali yaitu sebelum diberikan perlakuan (pre-test) dan setelah diberikan perlakuan (post-test).

\section{Pembahasan}

\section{Deskripsi Data Hasil Penelitian \\ Data Pre-test Keterampilan Proses IPA Kelas Eksperimen}

Pre-test keterampilan proses IPA kelas eksperimen dilakukan pada Senin tanggal 3 September 2018. Setelah diadakan pre-test data yang diperoleh kemudian diolah menggunakan bantuan software SPSS 16 for windows, untuk mengetahui data distribusi frekuensi pre-test pada kelas eksperimen. Data rincian data distribusi frekuensi pre-test keterampilan proses IPA dapat dilihat dalam tabel berikut. 


\section{SANG PENCERAH}

Volume 4, Nomor 2, Agustus 2018, H1m. 1-11

Ardy Lestary A.R.: Pengaruh Penggunaan Media Audio Visual ...

Tabel 1 Data Distribusi Frekuensi Pre-test keterampilan proses IPA Kelas Eksperimen

\begin{tabular}{lcc}
\hline \multicolumn{1}{c}{ Kriteria } & Frekuensi & Persentase (\%) \\
\hline Sangat Baik (85-100) & 0 & 0 \\
Baik (70-84) & 0 & 0 \\
Cukup (55-69) & 1 & 3,6 \\
Kurang (40-54) & 11 & 39,3 \\
Sangat Kurang (0-39) & 16 & \multicolumn{2}{c}{57,1} \\
\hline Total & 28 & \multicolumn{2}{c}{100,0} \\
\hline Rata-Rata & \multicolumn{3}{c}{$\mathbf{3 5 , 5 7}$} \\
Nilai Tertinggi & \multicolumn{2}{c}{$\mathbf{5 6}$} \\
Nilai Terendah & \multicolumn{2}{|c|}{} \\
\hline
\end{tabular}

\section{Data Pre-test Keterampilan Proses IPA} Kelas Kontrol

Pre-test keterampilan proses IPA kelas kontrol dilakukan pada Senin tanggal 3 September 2018. Setelah diadakan pre-test data yang diperoleh kemudian diolah menggunakan bantuan software SPSS 16 for Windows, untuk mengetahui data distribusi frekuensi pre-test pada kelas kontrol. Rincian data distribusi frekuensi dapat dilihat dalam tabel berikut.

Tabel 2 Data Distribusi Frekuensi Pre-test keterampilan proses IPA Kelas Kontrol

\begin{tabular}{|c|c|c|}
\hline Kriteria & Frekuensi & Persentase (\%) \\
\hline Sangat Baik (85-100) & 0 & 0 \\
\hline Baik (70-84) & 0 & 0 \\
\hline Cukup (55-69) & 0 & 0 \\
\hline Kurang (40-54) & 10 & 35,7 \\
\hline Sangat Kurang (0-39) & 18 & 64,3 \\
\hline Total & 28 & 100,0 \\
\hline Rata-Rata & \multicolumn{2}{|r|}{32,71} \\
\hline Nilai Tertinggi & \multicolumn{2}{|r|}{52} \\
\hline Nilai Terendah & \multicolumn{2}{|r|}{12} \\
\hline
\end{tabular}

\section{Data Pre-test Hasil Belajar IPA Kelas Eksperimen}

Pre-test hasil belajar IPA kelas eksperimen dilakukan pada Selasa tanggal 4 September 2018. Setelah diadakan pre-test data yang diperoleh kemudian diolah menggunakan bantuan software SPSS 16 for Windows, untuk mengetahui data distribusi frekuensi pre-test pada kelas eksperimen. Rincian data distribusi frekuensi dapat dilihat dalam tabel berikut.

Tabel 3 Data Distribusi Frekuensi Pre-test Hasil Belajar IPA Kelas Eksperimen

\begin{tabular}{|c|c|c|}
\hline Kriteria & Frekuensi & Persentase (\%) \\
\hline Sangat Baik (85-100) & 0 & 0 \\
\hline Baik (70-84) & 1 & 3,6 \\
\hline Cukup (55-69) & 11 & 39,3 \\
\hline Kurang (40-54) & 10 & 35,7 \\
\hline Sangat Kurang (0-39) & 6 & 21,4 \\
\hline Total & 28 & 100,0 \\
\hline Rata-Rata & & 48,86 \\
\hline Nilai Tertinggi & & 76 \\
\hline Nilai Terendah & & 24 \\
\hline
\end{tabular}

\section{Data Pre-test Hasil Belajar IPA Kelas Kontrol}

Pre-test hasil belajar IPA kelas kontrol dilakukan pada Selasa tanggal 4 September 2018. Setelah diadakan pre-test data yang diperoleh kemudian diolah menggunakan bantuan software SPSS 16 for Windows, untuk mengetahui data distribusi frekuensi pre-test pada kelas kontrol. Rincian data distribusi frekuensi dapat dilihat dalam tabel berikut.

Tabel 4 Data Distribusi Frekuensi Pre-Test Hasil Belajar IPA Kelas Kontrol

\begin{tabular}{lcc}
\hline Kriteria & Frekuensi & Persentase (\%) \\
\hline Sangat Baik (85-100) & 0 & 0 \\
Baik (70-84) & 0 & 0 \\
Cukup (55-69) & 10 & 35,7 \\
Kurang (40-54) & 11 & 39,3 \\
Sangat Kurang (0-39) & 7 & 25,0 \\
\hline Total & $\mathbf{2 8}$ & $\mathbf{1 0 0 , 0}$ \\
Rata-Rata & \multicolumn{3}{c}{$\mathbf{4 6 , 7 1}$} \\
Nilai Tertinggi & \multicolumn{3}{c}{$\mathbf{6 8}$} \\
Nilai Terendah & \multicolumn{3}{|c|}{} \\
\hline
\end{tabular}




\section{SANG PENCERAH}

Volume 4, Nomor 2, Agustus 2018, H1m. 1-11

Ardy Lestary A.R.: Pengaruh Penggunaan Media Audio Visual ...

\section{Data Post-test Keterampilan Proses IPA Kelas Eksperimen}

Post-test keterampilan proses IPA kelas eksperimen dilakukan pada Selasa tanggal 4 September 2018. Setelah diadakan post-test data yang diperoleh kemudian diolah menggunakan bantuan software SPSS 16 for Windows, untuk mengetahui data distribusi frekuensi post-test keterampilan proses IPA pada kelas eksperimen. Rincian data distribusi frekuensi dapat dilihat dalam tabel berikut.

Tabel 5 Data Distribusi Frekuensi Post-test keterampilan proses IPA Kelas Eksperimen

\begin{tabular}{|c|c|c|}
\hline Kriteria & Frekuensi & Persentase (\%) \\
\hline Sangat Baik (85-100) & 0 & 0 \\
\hline Baik (70-84) & 2 & 7,1 \\
\hline Cukup (55-69) & 23 & 82,1 \\
\hline Kurang (40-54) & 3 & 10,7 \\
\hline Sangat Kurang (0-39) & 0 & 0 \\
\hline Total & 28 & 100,0 \\
\hline Rata-Rata & & 62,14 \\
\hline Nilai Tertinggi & & 72 \\
\hline Nilai Terendah & & 48 \\
\hline
\end{tabular}

\section{Data Post-test Keterampilan Proses IPA} Kelas Kontrol

Post-test keterampilan proses IPA kelas kontrol dilakukan pada Selasa tanggal 4 September 2018. Data yang diperoleh kemudian diolah menggunakan bantuan software SPSS 16 for Windows, untuk mengetahui data distribusi frekuensi posttest keterampilan proses IPA pada kelas kontrol. Siswa pada kelas kontrol yang diajarkan menggunakan media gambar terlihat kurang begitu memperhatikan selama pembelajaran berlangsung. Siswa terlihat tidak begitu tertarik dengan materi yang disampaikan guru, siswa malah bermain sendiri dan terlihat tidak antusias dalam pembelajaran. Sehingga, diperoleh hasil post-test keterampilan proses IPA sebagai berikut.

\section{Tabel 6 Data Distribusi Frekuensi Post-test keterampilan proses IPA Kelas Kontrol}

\begin{tabular}{lcc}
\hline Kriteria & Frekuensi & Persentase (\%) \\
\hline Sangat Baik (85-100) & 0 & 0 \\
Baik (70-84) & 3 & 10,7 \\
Cukup (55-69) & 8 & 28,6 \\
Kurang (40-54) & 16 & 57,1 \\
Sangat Kurang (0-39) & 1 & 3,6 \\
Total & $\mathbf{2 8}$ & $\mathbf{1 0 0 , 0}$ \\
Rata-Rata & \multicolumn{3}{|c}{$\mathbf{5 3 , 8 6}$} \\
Nilai Tertinggi & \multicolumn{3}{c}{$\mathbf{7 2}$} \\
Nilai Terendah & \multicolumn{3}{|c}{$\mathbf{3 6}$} \\
\hline
\end{tabular}

Berdasarkan data pada tabel 4.6, diketahui bahwa post-test keterampilan proses IPA kelas kontrol diperoleh nilai ratarata sebesar 53,86 dengan kriteria kurang. Nilai tertinggi 72 dan nilai terendah 36 . Siswa yang memperoleh kriteria nilai baik sebesar 10,7\%, kriteria cukup sebesar 28,6\%, kriteria kurang sebesar $57,1 \%$ dan kriteria sangat kurang sebesar 3,6\%. Dilihat dari data tabel 12, nilai post-test keterampilan proses IPA siswa kelas kontrol yang menggunakan media gambar hasilnya lebih rendah bilaa dibandingkan dengan nilai post-test pada kelas eksperimen yang menggunakan media audio visual pembelajaran, sehingga pembelajaran menggunakan media audio visual pembelajaran terihat lebih efektif digunakan. Data nilai post-test keterampilan proses IPA kelas control.

\section{Data Hasil Observasi Keterampilan Proses IPA Kelas Eksperimen}

Hasil observasi keterampilan proses kelas eksperimen dilakukan pada saat pembelajaran berlangsung. Data yang 


\section{SANG PENCERAH}

Volume 4, Nomor 2, Agustus 2018, Hlm. 1-11

Ardy Lestary A.R.: Pengaruh Penggunaan Media Audio Visual ...

diperoleh kemudian diolah menggunakan bantuan software SPSS 16 for Windows, untuk mengetahui data distribusi frekuensi hasil observasi keterampilan proses pada kelas eksperimen. Data hasil observasi diperoleh dengan mengamati siswa selama proses pembelajaran. Setelah siswa memahami materi dari media audio visual, guru membagi siswa kedalam 8 kelompok dengan anggota 4 siswa untuk mengerjakan tugas LKS, siswa dengan antusias mengerjakan LKS. Hasil LKS kemudian di presentasikan di depan kelas dan dibahas bersama. Selama proses pembelajaran berlangsung observer mengamati dan mencatat bagaimana keterampilan proses siswa. Data nilai rata-rata hasil observasi keterampilan proses IPA dan rincian data distribusi frekuensi dapat dilihat dalam tabel berikut.

Tabel 7 Data Distribusi Frekuensi Rata-rata Observasi Keterampilan Proses IPA kelas eksperimen

\begin{tabular}{|c|c|c|}
\hline Kriteria & Frekuensi & Persentase (\%) \\
\hline Sangat Baik (85-100) & 2 & 7,1 \\
\hline Baik (70-84) & 18 & 64,3 \\
\hline Cukup (55-69) & 8 & 28,6 \\
\hline Kurang (40-54) & 0 & 0 \\
\hline Sangat Kurang (0-39) & 0 & 0 \\
\hline Total & 28 & 100,0 \\
\hline Rata-Rata & \multicolumn{2}{|c|}{73,21} \\
\hline Nilai Tertinggi & \multicolumn{2}{|c|}{85,00} \\
\hline Nilai Terendah & \multicolumn{2}{|c|}{56,25} \\
\hline
\end{tabular}

Data Hasil Observasi Keterampilan Proses IPA Kelas Kontrol

Hasil observasi keterampilan proses IPA kelas kontrol dilakukan pada saat pembelajaran berlangsung, dari pertemuan 1 sampai dengan pertemuan 4. Data yang diperoleh kemudian diolah menggunakan bantuan software SPSS 16 for Windows, untuk mengetahui data distribusi frekuensi hasil observasi keterampilan proses IPA pada kelas kontrol. Data hasil observasi keterampilan proses pada kelas kontrol diperoleh dengan mengamati setiap siswa selama proses pembelajaran berlangsung. Observer mengamati siswa dari kegiatan pembuka sampai penutup.Rincian data distribusi frekuensi dapat dilihat dalam tabel berikut.

\section{Tabel 9 Data Distribusi Frekuensi Observasi Keterampilan Proses IPA Kelas Kontrol}

\begin{tabular}{|c|c|c|}
\hline Kriteria & Frekuensi & Persentase (\%) \\
\hline Sangat Baik (85-100) & 0 & 0 \\
\hline Baik (70-84) & 11 & 39,3 \\
\hline Cukup (55-69) & 17 & 60,7 \\
\hline Kurang (40-54) & 0 & 0 \\
\hline Sangat Kurang (0-39) & 0 & 0 \\
\hline Total & 28 & 100,0 \\
\hline Rata-Rata & \multicolumn{2}{|c|}{66,29} \\
\hline Nilai Tertinggi & \multicolumn{2}{|c|}{75,00} \\
\hline Nilai Terendah & \multicolumn{2}{|c|}{55,00} \\
\hline
\end{tabular}

\section{Persentase Observasi Keterampilan Proses IPA Kelas Eksperimen- Kontrol}

Hasil perhitungan persentase hasil observasi keterampilan proses IPA pada kelas eksperimen dan kelas kontrol dapat dilihat pada tabel berikut.

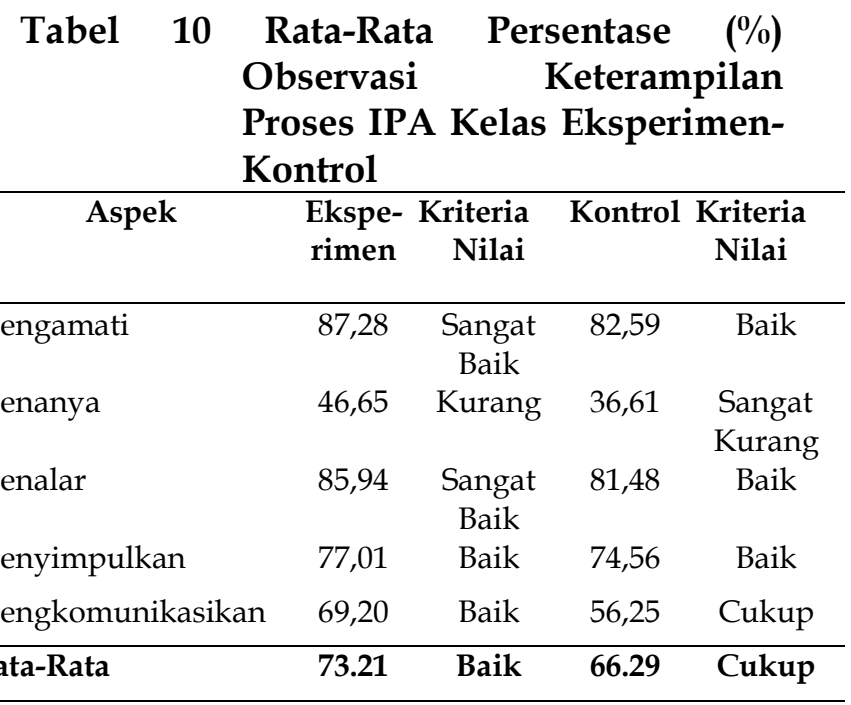




\section{SANG PENCERAH}

Volume 4, Nomor 2, Agustus 2018, Hlm. 1-11

Ardy Lestary A.R.: Pengaruh Penggunaan Media Audio Visual ...

\section{Data Post-test Hasil Belajar IPA Kelas Eksperimen}

Post-test hasil belajar IPA kelas eksperimen dilakukan pada Selasa tanggal 4 September 2018. Setelah diadakan post-test data yang diperoleh kemudian diolah menggunakan bantuan software SPSS 16 for Windows, untuk mengetahui data distribusi frekuensi post-test pada kelas eksperimen. Setelah siswa mempelajari materi mengenai pencernaan dan pernafasan hewan dan tumbuhan, di akhir pembelajaran keempat siswa diberikan post-test untuk mengukur keberhasilan siswa dalam memahami materi. Rincian data distribusi frekuensi dapat dilihat dalam tabel berikut.

Tabel 11 Data Distribusi Frekuensi Post-test Hasil Belajar IPA Kelas Eksperimen

\begin{tabular}{|c|c|c|}
\hline Kriteria & Frekuensi & Persentase (\%) \\
\hline Sangat Baik (85-100) & 6 & 21,4 \\
\hline Baik (70-84) & 19 & 67,9 \\
\hline Cukup (55-69) & 3 & 10,7 \\
\hline Kurang (40-54) & 0 & 0 \\
\hline Sangat Kurang (0-39) & 0 & 0 \\
\hline Total & 28 & 100,0 \\
\hline Rata-Rata & & 80 \\
\hline Nilai Tertinggi & & 92 \\
\hline Nilai Terendah & & 64 \\
\hline
\end{tabular}

\section{Data Post-test Hasil Belajar IPA Kelas Kontrol}

Post-test hasil belajar IPA kelas kontrol dilakukan pada Selasa tanggal 4 September 2018. Setelah diadakan post-test data yang diperoleh kemudian diolah menggunakan bantuan software SPSS 16 for Windows, untuk mengetahui data distribusi frekuensi posttest pada kelas kontrol. Pada kelas kontrol diberikan pembelajaran menggunakan media gambar. Setelah siswa mempelajari materi yang disampaikan dengan media gambar, siswa diberikan post-test di akhir pembelajaran keempat untuk mengukur keberhasilan siswa dalam memahai materi.
Rincian data distribusi frekuensi hasil posttest dapat dilihat dalam tabel berikut.

Tabel 12 Data Distribusi Frekuensi posttest Hasil Belajar IPA Kelas Kontrol

\begin{tabular}{lcc}
\hline Kriteria & Frekuensi & Persentase (\%) \\
\hline Sangat Baik (85-100) & 2 & 7,1 \\
Baik (70-84) & 13 & 46,4 \\
Cukup (55-69) & 11 & 39,3 \\
Kurang (40-54) & 2 & 7,1 \\
Sangat Kurang (0-39) & 0 & 0 \\
\hline Total & $\mathbf{2 8}$ & $\mathbf{1 0 0 , 0}$ \\
\hline Rata-Rata & $\mathbf{7 0 , 8 6}$ & \\
Nilai Tertinggi & $\mathbf{9 2}$ & \\
Nilai Terendah & $\mathbf{5 2}$ & \\
\hline
\end{tabular}

Setelah dilakukan penelitian, maka diperoleh data hasil penelitian. Pre-test keterampilan proses IPA dan hasil belajar IPA pada kelas eksperimen dan kelas kontrol dilaksanakan pada 4 September 2018. Hasil pre-test keterampilan proses IPA menunjukan nilai rata-rata pre-test keterampilan proses IPA antara kelas eksperimen dan kelas kontrol relatif sama yaitu kelas eksperimen sebesar 35,57 dan kelas kontrol 32,71. Nilai rata-rata pre-test hasil belajar IPA kelas eksperimen yaitu sebesar 48,86 dan kelas kontrol 46,71. Dan setelah dilakukan uji prasyarat normalitas dan homogenitas, kedua sampel tersebut dinyatakan berdistribusi normal dan memiliki kemampuan awal yang sama atau homogen sehingga dapat dilakukan penelitian pada kedua sampel.

Penelitian ini dilakukan selama 4 kali pertemuan untuk masing-masing kelas. Pembelajaran pada kelas eksperimen dilakukan dengan menggunakan media audio visual dengan materi proses pencernaan dan pernafasan pada manusia dan hewan. Audio visual proses pencernaan manusia dan hewan berisi animasi gambar dan suara yang dimulai dari makanan masuk ke dalam mulut sampai sisa makanan keluar melalui anus. Proses pernafasan juga 


\section{SANG PENCERAH}

Volume 4, Nomor 2, Agustus 2018, Hlm. 1-11

Ardy Lestary A.R.: Pengaruh Penggunaan Media Audio Visual ...

berisi animasi gambar dan suara yang menjelaskan proses pernafasan manusia dan hewan mulai dari udara masuk ke lubang hidung sampai udara keluar lagi melalui hidung. Sedangkan pembelajaran pada kelas kontrol menggunakan media gambar untuk menjelaskan proses pencernaan dan pernafasan pada manusia dan hewan.

Setelah diterapkan pembelajaran dengan menggunakan media audio visual pembelajaran pada kelas eksperimen dan pembelajaran menggunakan media gambar sederhana kelas kontrol diperoleh hasil posttest keterampilan proses IPA pada kelas eksperimen 62,14 lebih besar dari nilai ratarata kelas kontrol yaitu 53,86 dengan selisih 8,28 . Ini memperkuat bukti bahwa penggunaan media audio visual pembelajaran lebih efektif digunakan pada materi pencernaan dan pernafasan manusia dan hewan, dibandingkan dengan menggunakan media gambar.

Pada aspek mengamati kelas eksperimen memperoleh nilai sebesar 87,28\% dengan kriteria sangat baik, lebih tinggi dibandingkan pada kelas kontrol yaitu $82,59 \%$ dengan kriteri baik. Persentase keterampilan proses IPA pada aspek mengamati di kelas eksperimen lebih tinggi dibandingkan kelas kontrol karena siswa kelas eksperimen lebih antusias dan lebih termotivasi untuk memperhatikan informasi yang disampaikan dalam bentuk audio visual. Siswa terlihat lebih tenang dan memperhatikan setiap informasi yang disajikan, sehingga persentase rata-rata nilai keterampilan pada aspek mengamati kelas eksperimen lebih tinggi daripada aspek lainnya.

Persentase terendah rata-rata keterampilan proses IPA diperoleh pada aspek menanya. Persentase rata-rata aspek menanya pada kelas kontrol yaitu sebesar $36,61 \%$ dengan kriteria sangat kurang, lebih rendah dibandingkan dengan kelas eksperimen yaitu 46,65\% dengan kriteria kurang. Persentase aspek menanya lebih rendah bila dibandingkan dengan aspek lainnya karena siswa di kelas eksperimen dan kontrol terlihat kurang antusias dalam mengajukan sebuah pertanyaan dan siswa juga kurang mendapat bimbingan untuk dapat mengajukan pertanyaan dengan baik. Sehingga, siswa terlihat main-main sendiri dan kurang termotivasi untuk bertanya. Seharusnya siswa lebih diberikan kesempatan secara luas untuk bertanya dan dibimbing guru agar siswa dapat mengajukan pertanyaan dengan baik.

Berdasarkan data hasil penelitian keterampilan proses IPA menunjukkan nilai hasil rata-rata post-test dan hasil observasi keterampilan proses IPA kelas eksperimen lebih tinggi bila dibandingkan dengan kelas kontrol. Setelah dilakukan analisis data hasil penelitian, diperoleh hasil bahwa terdapat pengaruh penggunaan media audio visual pembelajaran terhadap keterampilan proses IPA siswa.

Post-test hasil belajar IPA diperoleh nilai rata-rata post-test hasil belajar IPA siswa pada kelas eksperimen 80,00 dan kelas kontrol 70,86. Berdasarkan data tersebut menunjukkan nilai rata-rata post-test hasil belajar IPA kelas eksperimen lebih tinggi bila dibandingkan dengan kelas kontrol. Berdasarkan pengamatan dan observasi selama proses pembelajaran berlangsung, siswa pada kelas eksperimen yang diajaran menggunakan media audio visual pembelajaran terlihat lebih senang dan tertarik dalam memperhatikan materi yang disampaikan.

Dalam pelaksanaan kegiatan pembelajaran dan tugas kelompok LKS menggunakan audio visual, siswa tidak banyak menemui kesulitan dan berhasil mengerjakan tugas dengan baik. Dengan demikian, penggunaan media audio visual pembelajaran dapat dikatakan lebih efektif dan dapat menciptakan suasana belajar yang menarik, menyenangkan, sehingga siswa menjadi lebih memahami materi yang 


\section{SANG PENCERAH}

Volume 4, Nomor 2, Agustus 2018, Hlm. 1-11

Ardy Lestary A.R.: Pengaruh Penggunaan Media Audio Visual ...

disampaikan dan memoeroleh hasil belajar yang lebih optimal.

Berdasarkan data hasil penelitian, dapat dilihat bahwa nilai keterampilan proses IPA pada siswa meningkat lebih baik dan nilai hasil belajar IPA pada siswa juga menjadi lebih baik. Hal itu memperkuat bukti bahwa ada hubungan antara keterampilan proses IPA dengan hasil belajar IPA pada siswa. Setelah dilakukan pengujian, hasil analisis korelasi antara keterampilan proses IPA dan hasil belajar IPA juga terbukti ada hubungan dengan diperoleh nilai korelasi sebesar 0,945 untuk kelas eksperimen dan 0,944 kelas kontrol yang berarti ada hubungan positif sangat kuat. Sehingga dapat disimpulkan bahwa terdapat hubungan positif sangat kuat antara keterampilan proses IPA dan hasil belajar IPA siswa.

Dari beberapa pendapat di atas yang berkaitan dengan keterampilan proses IPA dan hasil belajar IPA siswa relevan dengan hasil penelitian yang peneliti lakukan. Hasil penelitian menunjukan bahwa rata-rata nilai keterampilan proses IPA dan rata-rata hasil belajar IPA siswa pada kelas eksperimen lebih tinggi bila dibandingkan dengan nilai rata-rata pada kelas kontrol. Sehingga dapat disimpulkan terdapat pengaruh penggunaan media audio visual pembelajaran terhadap keterampilan proses IPA dan hasil belajar IPA pada siswa Kelas V SD Negeri 1 Boneatiro tahun ajaran 2018/2019 dan terdapat hubungan positif sangat kuat antara keterampilan proses IPA dengan hasil belajar IPA pada siswa Kelas V SD Negeri 1 Boneatiro tahun ajaran 2018/2019.

\section{Simpulan}

Simpulan penelitian ini bahwa (1) Terdapat pengaruh penggunaan media audio visual pembelajaran terhadap keterampilan proses IPA pada siswa Kelas V SD Negeri 1 Boneatiro. Hal ini ditunjukkan pada perbedaan nilai rata-rata post-test keterampilan proses IPA siswa pada kelas eksperimen yaitu 62,14 lebih besar dari nilai rata-rata kelas kontrol yaitu 53,86; (2) Terdapat pengaruh penggunaan media audio visual pembelajaran terhadap hasil belajar IPA pada siswa kelas V Kelas V SD Negeri 1 Boneatiro Hal ini ditunjukkan pada perbedaan nilai rata-rata post-test hasil belajar IPA siswa pada kelas eksperimen 80,00 lebih besar dari nilai rata-rata kelas kontrol yaitu 70,86; dan (3) Terdapat hubungan positif sangat kuat antara keterampilan proses IPA dengan hasil belajar IPA pada siswa Kelas V SD Negeri 1 Boneatiro. Hal ini ditunjukkan pada koefisien korelasi Sig. (2- tailed) antara keterampilan proses IPA kelas eksperimen dan post-test hasil belajar kelas eksperimen sebesar 0,000 < 0,05 dan koefisien korelasi Sig. (2- tailed) antara keterampilan proses IPA kelas kontrol dan post-test hasil belajar kelas kontrol sebesar 0,000 $<0,05$. Sedangkan nilai korelasi kelas eksperimen sebesar 0,945 dan kelas kontrol sebesar 0,944.

\section{Daftar Pustaka}

Adi Thomas. 2015. Jurnal Penelitian. Peningkatan Kreatifitas Guru Sekolah Dasar Melalui Media Pembelajaran Berbasis Komputer. Diterbitkan. Universitas Bung Hatta.

Afrilindo Hagi. 2014. Jurnal Ekonomika. Pengaruh Aktivitas Belajar dan Kemandirian Dalam Mengerjakan Tugas Terhadap Hasil Belajar Siswa. Diterbitkan. STKIP PGRI Sumbar.

Daryanto. 2014. Pendekatan Pembelajaran Saintifik Kurikulum 2013. Yogyakarta: Gava Media.

Dwi Martia. 2015. Skripsi. Keefektifan Penerapan Pendekatan Proses Dalam Pembelajaran IPA Terhadap Minat Belajar Siswa Kelas 


\section{SANG PENCERAH}

Volume 4, Nomor 2, Agustus 2018, Hlm. 1-11

Ardy Lestary A.R.: Pengaruh Penggunaan Media Audio Visual ...

IV SD Negeri Golo Yogyakarta. Diterbitkan. Uuniversitas Negeri Yogyakarta.

Epy Purwasih. 2013. Jurnal Penelitian. Peranan Penggunaan Media Audio Visual Dalam Meningkatkan Minat Belajar Anak Di Kelompok B Terpadu Kabupaten Parigi. Diterbitkan. Universitas Tadulako.

Eveline Siregar \& Hartini. 2014. Teori Belajar dan Pembelajaran. Bogor: Ghalia Indonesia.

Evi Nur Eka Purnamasari. 2012. Skripsi. Pengaruh Penggunaan Media Video Pembelajaran terhadap Pemahaman Konsep Ilmu Pengetahuan Alam pada Siswa Kelas IV SD Negeri 2 Tamansari dan SD Negeri 2 Karanggude, Karanglewas, Banyumas. Diterbitkan. Universitas Negeri Yogyakarta.

Ferlianus. 2014. Artikel Penelitian. Pengaruh Media Audio Visual Terhadap Kemampuan Memahami Makna Puisi Oleh Siswa SD Tahun Pelajaran 2014/2015. Diterbitkan.

Helminsyah. 2014. Jurnal Tunas Bangsa. Pengaruh Penggunaan CTL Dalam Meningkatkan Ketuntasan Prestasi Belajar IPA Pasa Siswa Kelas V SD Negeri 8 Banda Aceh. Diterbitkan. STKIP Bina Bangsa Getsempena.

Heryanto. 2015. Jurnal Penelitian. Peningkatan Hasil Belajar Murid Dalam Pembelajaran IPA Menggunakan Metode Inkuiri Di Sekolah Dasar. Diterbitkan. FKIP UNTAN.

Kinsun Anastasia. 2014. Artikel Penelitian. Peningkatan Hasil Belajar Siswa Pada Pembelajaran Bahasa Indonesia Dengan Model Kontekstual Kelas IV. Diterbitkan. Universitas Tanjungpura Pontianak.
Kustandi Cecep. 2013. Media Pembelajaran Manual dan Digital Edisi Kedua. Bogor: Ghalia Indonesia.

Mariko Selli. 2014. Jurnal Formatif. Pengaruh Strategi Pembelajaran Berbasis Multimedia Interaktif Terhadap Hasil Belajar Fisika Pada Materi Optika Geometri. Diterbitkan. Universitas Indraprasta.

Muakhirin Binti. 2014. Jurnal Ilmiah. Peningkatan Belajar IPA Melalui Pendekatan Pembelajaran Inkuiri Pada Siswa SD. Diterbitkan. Jurnal Ilmiah Guru No.01/Tahun XVII/Mei 2014.

Ni Nym, dkk. 2013. Jurnal Penelitian. Pengaruh Model Pembelajaran Scramble Berbantuan Media Video terhadap Hasil Belajar IPA Siswa Kelas IV SD di Gugus V Kecamatan Buleleng. Diterbitkan. Udiksha.

Nurrahman Arief. 2016. Jurnal Pendidikan. Pengaruh Persepsi Siswa Mengenai Strategi Pembelajaran, dan Penguasaan Materi Pembelajaran Terhadap Prestasi Belajar. Diterbitkan. Universitas Negeri Yogyakarta.

Nissa Estika. 2016. Penggunaan Media Audio Visual Untuk Meningkatkan Motivasi Belajar Mata Pelajaran IPS Pada Siswa Kelas V Di MI Al Falah Pagu Wates Kabupaten Kediri. Diterbitkan. UIN Maulana MALIK Ibrahim.

Novianti. 2014. Jurnal Penelitian. Integrasi NilaiNilai Islam Dalam Pembelajaran IPA DI Sekolah. Diterbitkan. IAIN Syekh Nurjati Cirebon.

Noviana. 2016. Jurnal Penelitian. Peningkatan Hasil Belajar Menyusun Laporan Dengan Pembelajaran Kooperatif Tipe Team (TAI). Diterbitkan. Universitas Negeri Semarang. 


\section{SANG PENCERAH}

Volume 4, Nomor 2, Agustus 2018, Hlm. 1-11

Ardy Lestary A.R.: Pengaruh Penggunaan Media Audio Visual ...

Rahman. 2014. Artikel Penelitian. Peningkatan Pembelajaran IPA Energi dan Penggunaanya Melalui Metode Eksperimen Di Sekolah Dasar. Diterbitkan. Universitas Tanjungpura Pontianak.

Sugiyono. 2012. Metode Penelitian Pendidikan Pendekatan Kuantitatif, Kualitatif, RED. Bandung: Alfabeta.

Susanto Ahmad. 2013. Teori Belajar dan Pembelajaran di Sekolah Dasar. Jakarta: Kencana Prenada Media Group.

Suryani Karmila. 2013. Artikel Penelitian. Peningkatan Kreativitas Guru Sekolah Dasar Melalui Media Pembelajaran Berbasis Komputer. Diterbitkan. Universitas Bung Hatta. 